\title{
Interests, Trust and Security in US-Jordanian Nuclear Relations
}

\author{
Imad El-Anis \\ Senior Lecturer in International Relations at the Nottingham Trent University
}

\begin{abstract}
This article explores the relationship between Jordan and the United States (US) in the field of nuclear energy cooperation. Since 2010 the Jordanian government has accelerated its plans for a nuclear energy program and has engaged with multiple partners around the world in order to agree terms for cooperation in technology exchange, monitoring, and the construction of infrastructure. Bilateral negotiations between the US and Jordan for a " 123 " nuclear cooperation agreement were underway by early 2008, but were suspended in 2011 without an agreement being reached. Jordanian nuclear energy policy has been spurred by energy security considerations (as it currently imports 97 percent of its energy needs) and the discovery of up to 120,000 tonnes of uranium ore in Jordan. At the same time, the US is primarily interested in management of nuclear technology proliferation. This work considers the perceptions of self and other in Jordanian and US policymaking in order to understand why bilateral cooperation has not materialized and what this means for nuclear proliferation in Jordan. This study finds that the USJordanian negotiations have been impeded by contradictory objectives and perceptions, and a "123" agreement is not likely in the short to medium term, but that development of Jordan's nuclear energy program will likely continue regardless.
\end{abstract}

Keywords: Jordan, United States, energy security, nuclear energy, cooperation

In the past decade, nuclear technology proliferation in the Middle East has increased rapidly. A number of states, including Jordan, Egypt, the United Arab Emirates (UAE), Saudi Arabia, Yemen, and of course Iran, are currently developing nuclear programs. Some of these programs are quite advanced (as in Iran), while others are at an early stage of planning (such as in Jordan). In all cases, bilateral and multilateral negotiations with nuclear supplier states ${ }^{1}$ under international law have taken place with varying degrees of success. In the current climate, enhancing bilateral and multilateral cooperation in the field of nuclear energy may be the most effective way to ensure that the proliferation of nuclear technologies for

Copyright @ 2014 SAGE Publications www.sagepublications.com (Los Angeles, London, New Delhi, Singapore and Washington DC)

Vol 30(4): 459-482. DOI: 10.1177/0169796X14545582 
peaceful purposes does not lead to these same technologies being used for non-peaceful purposes (the proliferation of nuclear weapons). However, some scholars argue that the proliferation of nuclear technology and nuclear weapons are directly linked (Fuhrmann, 2009a; Kroenig, 2009a). In this view, transparency, international cooperation, and the existence of security threats are all seen to have significant impacts on the direction nuclear technology programs take.

Nuclear proliferation in the Middle East is at a crossroads, with the potential for relatively insulated programs (as has taken place in Iran) to develop in countries like Egypt (a worrying prospect given political instability there), Saudi Arabia, and Jordan. Alternatively, as the case of the UAE demonstrates, transparent and multilateral programs may also emerge, but these are based on international negotiations and the cooperation that they embed. Understanding the causes of the success or failure of international negotiations aimed at promoting international cooperation is, therefore, important. In the case of US-Jordanian relations, bilateral nuclear cooperation negotiations took place between 2008 and 2011 but were unsuccessful. Analyzing the reasons why may prove useful in understanding whether similar negotiations with other states in the region and beyond will succeed or fail, as well as whether or not nuclear programs in the Middle East will be insulated or transparent.

Bilateral nuclear cooperation agreements, including " 123 " agreements, ${ }^{2}$ allow for the exchange of technology, expertise, material, financial capital, and the development of infrastructure between the signatories, and so can be useful when non-nuclear states seek to establish nuclear energy programs. Furthermore, without such an agreement, corporations based in one state will often not be authorized to pursue contracts with the foreign government seeking nuclear energy. For states seeking to develop nuclear energy, these agreements, and especially " 123 " agreements with the US, are important. However, in the case of "123" agreements, the applicant state must adhere to the US-mandated nuclear non-proliferation norms (National Nuclear Security Administration [NNSA], 2012). The failure to sign a "123" agreement with the US represents a significant problem for both states - hindering the development of its program in the case of the former and not meeting goals on non-proliferation for the latter.

This article examines the reasons why the US-Jordanian negotiations failed and what the impact on nuclear proliferation in Jordan may be and whether a return to negotiations is possible in the future. Specifically, I analyze decision-makers' perceptions of energy insecurity in Jordan, 
the political economy of nuclear energy there. I also explore how the two governments' perceptions of these issues differ. This is achieved by employing a theoretical model that draws upon a constructivist analysis of agency, self-perception, and perceptions of the "other" to determine how interests, threats/security, and policy have been identified by the governments in Amman and Washington. This study also seeks to test the applicability of this model to this specific case of bilateral nuclear cooperation negotiations and to offer conclusions as to its applicability to nuclear cooperation agreements in general.

I argue that Jordanian decision-makers believe that Jordan faces severe energy insecurity; that they believe this is one of the most significant longterm security threats Jordan faces as it undermines development; and that the Jordanian government perceives nuclear energy as a solution. At the same time, I argue that the US government does not hold the same perception of the Jordanian nuclear energy program and wants Jordan to adhere to the US-mandated non-proliferation norms. ${ }^{3}$

\section{Analyzing Nuclear Technology Proliferation}

Some scholars (Fuhrmann, 2009b; Gartzke \& Jo, 2009; Sagan, 1996) emphasize the importance of security threats as leading states to pursue nuclear weapons and claim that this policy is more likely where civilian nuclear technologies are present (especially when cooperation with a nuclear supplier state takes place). However, in over six decades of international nuclear technology cooperation and proliferation, only four states outside of the five victors of World War II (the original nuclear power states) have developed nuclear weapons, and each one faced a clear external existential threat from external states with which each had already fought at least one conventional war at the time that they began to pursue nuclear weapons. ${ }^{4}$ But this leaves unaddressed questions of nuclear proliferation where external existential threats are not present, are unlikely to emerge in the short to medium (or even long) term, and does not account for other forms of insecurity.

Matthew Fuhrmann (2009b) argues that there can be a direct correlation between the proliferation of civilian nuclear technology through international cooperation and the proliferation of nuclear weapons. He draws a link between the development of nuclear capacity for civilian purposes through the transfer of sensitive technologies, the training of personnel, and the construction of nuclear infrastructure, and external security threats in encouraging decision-makers to pursue 
nuclear weapons. However, Fuhrmann does not offer a discussion of how security threats are identified by decision-makers and how their responses are formed. In this article, I explore these questions by examining the role of the perceptions of decision-makers in Amman and Washington. I analyze how decision-makers perceive threats and what security issues are significant in shaping policy with regards to bilateral nuclear cooperation. Here, self-perceptions of rights, roles, responsibilities, security/insecurity, interests, and capabilities (agency) have been analyzed, along with perceptions of the other with regards to these issues.

Other work considers why nuclear supplier states cooperate with those pursuing civilian nuclear capabilities. Fuhrmann (2009a, p. 182), for example, argues that states provide nuclear assistance to: "(1) strengthen their allies and alliances, (2) to strengthen their relationship with enemies of enemies, and (3) to strengthen existing democracies and bilateral relationships with these countries (if the supplier is also a democracy)." However, in the case of the US-Jordanian negotiations, Fuhrmann's analysis is only partially applicable and does not fully explain why negotiations broke down in 2011. The first of the above statements does apply to Jordan (it being a close ally of the US), the second statement partially applies (for example, Jordan supporting US policy toward Iran), and the third statement does not (Jordanian governance has some democratic characteristics but is not democratic by the vast majority of accounts). But this approach does not explain the relationship between the three defining characteristics, and does not account for variations in how alliances, enemies, democracies are defined, leading to further questions being raised. Can one or more of these statements be partially applicable for nuclear cooperation to be forthcoming? How do nuclear supplier states account for variations in the nature of the relationships with other states? How do they determine the extent to which a state is an ally in the absence of formal bilateral treaties (which are increasingly rare)? Are their comparative variations in how close allies can be and how much of an enemy of your enemy another state may be? How democratic must states be to fit with the third statement (after all, there is no one universally applicable democratic model; see Andrain \& Smith, 2006)?

In a similar way, Leeds, Long \& Mitchell (2000) also focus on the strategic interests of supplier states and how these determine whether they cooperate with states seeking nuclear assistance, but these studies tend to take strategic interests for granted as existing outside of the views and cognitive capacities of the decision-makers responsible for policymaking. As Jan Ruzicka and Nicholas Wheeler (2010) demonstrate, attention 
also needs to be paid to intangible features of international relations and foreign (especially nuclear) policymaking in order to present more complete conclusions on specific cases of bilateral nuclear cooperation. Ruzicka and Wheeler focus on trust as a key issue in determining the existence of/lack of cooperation between states in nuclear cooperation, and conclude that this factor has a significant impact on decision-makers and their choices of whether to cooperate with others or not. The current study seeks to develop an understanding of why the US-Jordanian negotiations failed, as well as to debate on why and when states engage in nuclear cooperation more generally, by exploring how individual and collective perceptions of interests, insecurity, rights, roles, and other factors influence state policy.

Matthew Kroenig (2009a) highlights that much literature on nuclear proliferation tends to focus on "the demand side of nuclear proliferation" (ibid., p. 114) and offers a counter analysis that focuses on the supply side. His analysis demonstrates that "the strategic environment of the nuclear supplier" (ibid., p. 127) along with its strategic interests play a significant role in promoting or hindering bilateral nuclear cooperation. The data Kroenig's analysis is based upon are compelling; however, by focusing on one side of the relationship (the supply side), space is left for questions about the nature of bilateral relationships and the impact the combination of factors on both the demand side and supply side have on nuclear cooperation. Analyzing both sides at the same time can be useful here. Furthermore, questions can be raised regarding how the strategic environment and strategic interests are identified by decision-makers and how they can be analyzed by observers as these can be relative to time and space. Kroenig (2009b) also explores the potential impacts on nuclear weapons proliferation that the export of certain types of sensitive technologies can have (again, a supply-side analysis), which reinforces earlier conclusions with its comprehensive data analysis. It is useful here to consider work by Grzelczyk (2009) which discusses issues of transparency and the monitoring of the use of nuclear technologies in states that have been supplied with material via international cooperation of one kind or another. Grzelczyk demonstrates that differences in the level of transparency and multilateralism in a state's nuclear programs can have an impact on how external actors (including supplier states) behave toward it. This article engages with both areas of discussion at the same time in considering the US and Jordanian policy.

But understanding and explaining a state's national interests is not as straightforward as some approaches assume. By using a constructivist 
framework, Jutta Weldes (1996) offers a good overview of approaches to national interests, identifying two broad categories: one camp that sees little value in the term due to its indeterminate meaning, oversimplification, and commonsensical appeal; and a second that views the national interest as a key concept that should be central to our study of state behavior (ibid., pp. 275-276). Weldes (ibid., p. 276) sits within this latter camp and argues that "the national interest is important to international politics... [because] it is through the national interest that policy-makers understand the goals to be pursued by a state's foreign policy." Weldes explores how national interests, and by extension policy, can be conceptualized and demonstrates that analyzing state policy as a social construction can be beneficial. She argues that interpretation, language, and cognitive representation play important roles in determining interests and policy, and that these, as Alexander Wendt (1992) has demonstrated, can vary over time and space. I adopt a similar approach to Weldes, which utilizes principles of social constructivism pertaining to individual and group perceptions (discussed next), in this study to explore the interests, policies, and preferences of the Jordanian and US governments.

\section{Perceptions, Agency, and Decision-making}

To more fully understand why the US-Jordanian " 123 " negotiations failed, it is necessary to consider the ways in which the respective governments' interests and policies have been constructed. In order to do this, we need to consider the collective and individual perceptions of the decision-makers, in particular with regard to the Jordan's energy insecurity, rights under the nuclear Non-Proliferation Treaty (NPT), and the potential for nuclear energy to ensure energy security. This is because viewing states as unitary actors with a single identity and set of goals that remain static for long periods of time and only change slowly restricts our understanding of how governments, civil, and professional (especially the scientific community) operate, and how their agency and perceptions informs overall state policy. As Weldes (1996, p. 280) states, "the political and historical context in which national interests are fashioned, the intersubjective meanings which define state identities and interests, cannot arbitrarily be restricted to those meanings only produced in inter-state relations. After all, states are only analytically, but in fact, unitary actors." Here, the views of the decision-makers responsible for overarching policymaking and bilateral negotiations (the executive level of government - King Abdullah II and the Royal Court in Jordan, and the 
White House in the US; and specialized agencies - the Jordanian Atomic Energy Commission [JAEC] and the US Department of State's Office for Nuclear Energy Safety and Security) are central in determining policy.

Jordanian self-perceptions and the US perceptions of Jordan and its energy security situation are equally important in understanding the failure to successfully negotiate a " 123 " nuclear cooperation agreement. In an interesting and timely study that builds on earlier work (see Boulding, 1959; Jervis, 1976), Hatem S. Abu-Lebdeh (1997) argued that national perceptions are pivotal in influencing the Jordanian-US relationship in general, and that their perceptions often differ from each other. Abu-Lebdeh argued that Jordanian decision-makers tend to perceive themselves, and Jordan in general, as beset with development and security challenges; as a key US ally and moderating force in regional relations; and as having legitimate needs that must be pursued. On the other hand, the US decision-makers' perceptions of Jordan are influenced by broader international contexts and are shaped by foreign policy goals which are grand and larger than just the interests of one small state.

Governmental decision-making can be approached in different ways but it is perhaps most useful to envision decision-making as constituted by a series of different processes, actors, and relationships that overlap and reinforce each other. The principle of Joseph Nye's three-dimensional chess game model is useful to reflect upon here (Nye, 2004). Domestic and foreign policymaking are built on complex mechanisms for processing and communicating information, reconciling competing interests and demands/constraints, and producing decisions to be acted upon (Milner, 1997). At different levels of analysis within decision-making bodies, these mechanisms can differ. The influence of perceptions can be seen to take place at one of these levels.

The creation of perceptions and how they impact decision-making is formed by three elements: first, self-perception (including of one's own interests, rights, and needs); second, perception of the other (including their interests, rights, and needs); and finally, one's agency (goals and capabilities). Policy is formed at the nexus where these three elements meet, influencing and reinforcing each other. In any bilateral relationship, cooperation is determined by the compatibility of this nexus in each internal decision-making process. If the nexus of perceptions and agency are compatible with each other - the sum of the perceptionsagency interaction results in policies that do not hinder or interfere with those of the other actor - then cooperation is likely to result. Where the perceptions-agency nexus are not only compatible but mirror each 
other-the sum of the perceptions-agency interaction results in policies which directly support each other-then bilateral cooperation is certain to occur. At the same time, when the perceptions-agency nexus are not compatible with each other-the sum of the interactions results in policies which interfere, hinder, or directly oppose each other - then cooperation is not possible. Identifying the relevant perceptions and level of agency in the US-Jordanian nuclear technology relationship is, therefore, necessary in explaining the failure to cooperate on this issue.

Consideration also needs to be given to how decision-makers perceive their country's energy security situation. Energy security is a key concern for all functioning states and markets and directly effects political and economic stability (Spero, 1973). Energy security is fundamentally about two things: the actual supply-demand balance and perception. David Deese (1979, p. 140) summarizes energy security as "a condition in which a nation perceives a high probability that it will have adequate energy supplies at affordable prices." As such, governmental perceptions of energy security are important in determining energy security-it is perception that, in effect, determines the level of demand for energy supplies that are necessary in order to achieve a measure of energy security. In the coming decades, it is likely that the pursuit of energy security will become an increasingly sensitive issue that plays out at the international level, perhaps leading to conflict (Moran \& Russell, 2009). Furthermore, the interdependent nature of the domestic and international realms in an ever-globalizing and integrating world system results in a proliferation of challenges which influence policy responses.

In the case of Jordanian-US nuclear energy, a process exists whereby a challenge/problem is identified, interests and capabilities considered, and domestic and foreign policies developed in order to respond to it. Here, the perceptions-agency nexus found in our model of governmental decision-making influences the domestic and foreign policy responses that seek to attend to the original challenge/problem. For Jordan, the challenge is resource scarcity and energy insecurity which lead to vulnerability. This results in a consideration of Jordanian interests and capabilities (agency) and the creation of policies that are shaped by perceptions of self and other. For the US, the challenge/problem is managing international nuclear technology proliferation, which represents a key security challenge in the post-9/11 world and increases US vulnerability (in the form of nuclear-armed rogue states, terrorist activity, and so on). Washington constantly reviews its interests and capabilities in managing 
this international issue. Again, here, the perceptions-agency nexus in government circles influences the US domestic and foreign policy responses.

\section{Energy Insecurity and Jordan's Nuclear Policy}

There are two key structural characteristics which reinforce Jordanian decision-makers' view of Jordan's energy security problem. The first is that Jordan has very few natural resources of any kind and has practically no reserves of useable hydrocarbons - and so relies almost entirely on imports of these fuels. The second is that domestic sources of renewable energy that could be utilized to increase its energy security are largely ignored. According to the Chairman of the JAEC, Dr Khaled Touqan, the Jordanian government is quite occupied with the problems of the country's resource scarcity, which acts as one of the main influences on its national self-perception (Touqan, 2012). Unlike the majority of its neighbors, Jordan does not possess many natural resources in sufficient measure to meet its own demands. Jordan is the fourth-poorest state in the world in terms of freshwater sources (Aquastat), has no crude oil reserves and irrelevant natural gas reserves, but does have oil shale deposits. However, the extent of these reserves is not yet known (Luck, 2012b; Obeidat, 2012). Furthermore, due to geostrategic processes in the Middle East, Jordan is extremely vulnerable to external events that can disrupt both its energy supply and market volatility.

The 2003 war in Iraq, for example, cut off imports of oil which accounted for virtually all of Jordan's total oil supplies, meaning these supplies had to be replaced through agreements with other regional oil producers (Awad, 2009, p. 5). More recently, the regime change process in Egypt has disrupted supplies of natural gas to Jordan (which the former supplies through the El-Arish pipeline in the Sinai Peninsula [which had also supplied Israel with natural gas until late 2011]) due to sabotage on the pipeline (Obeidat, 2011). Since spring 2011, this has cost Jordan approximately $\$ 2.4$ billion due to converting power stations to use diesel and using Jordan's strategic reserves of hydrocarbons (Luck, 2012a). At the same time, as international energy supplies become increasingly vulnerable, domestic electricity demand in Jordan is expected to triple to 8,000 MW by 2030, further compounding its insecurity (Abu-Dabbouh, 2012).

Jordanians have a per capita freshwater consumption rate of less than 200 cubic meter $\left(\mathrm{m}^{3}\right)$ per year-well below the United Nations (UN)-designated water poverty line of $1,000 \mathrm{~m}^{3}$ per year (El-Ashry, Saab \& Zeitoon, 2010, p. 3). Having access to sufficient freshwater is 
central for agricultural and industrial development, reducing poverty, raising living standards, and better healthcare, and as such the implications of Jordan's freshwater scarcity are profound. It is generally accepted that one of the key pillars of any program in Jordan aimed at increasing freshwater supply hinges on desalinating sea water. However, this will require significant amounts of energy and therefore will require even greater energy imports if domestic energy sources are not developed. Already, total oil demand stands at approximately 110,000 barrels per day, all of which is imported from neighboring states, while total natural gas consumption is 3.01 billion $\mathrm{m}^{3}$ per year, of which 2.85 billion $\mathrm{m}^{3}$ is imported. The total cost of Jordan's energy imports was over US\$ 3.5 billion in 2011 (CIA World Factbook, 2011; UN Comtrade). These energy imports represented 25 percent of the government's budget for 2011 and were key causes of the budget deficit of around 10 percent of gross domestic product (GDP) that Jordan has constantly faced for the past decade or so.

The problem of resource scarcity is magnified by Jordan's developmental needs which are reliant on the availability of fuels at reasonable prices. The Jordanian economy has traditionally been characterized by a low level of industrial output, limited agricultural production, and the dominance of the services sector (El-Said, 2002, pp. 254-277). However, since the early 1990s, economic restructuring in Jordan has led to more emphasis on the need for industrial production, especially in higher valueadded manufacturing (see Knowles, 2005). The success of these and other industries, however, relies on the availability of cheap and stable supplies of energy in the long term. The current framework of Jordanian energy supply (foreign imports of hydrocarbons at volatile and high prices with no real domestic energy supply) is not conducive to long-term economic development and the Jordanian government is acutely aware of this.

Reinforcing Jordan's reliance on hydrocarbon imports is the underdeveloped nature of its domestic renewable energy industry. Use of renewable energy sources is extremely limited compared to Jordan's potential in this field. In particular, solar energy represents a vastly underutilized energy source in Jordan which receives some of the highest levels of concentrated solar energy in the world (Maytah, 2012a). According to Ayman Maytah, ${ }^{5}$ solar energy for household use (mainly photovoltaic roof installations) is currently only used on 10 percent of Jordanian buildings (Maytah, 2012b). Wind, thermal, and other renewable energy sources are not employed in Jordan. While there are initiatives underway to develop solar energy capacity in Jordan, these efforts are being led by the private 
sector and university-based scientific and technological communities. However, governmental support for these projects is limited and the development of a nuclear energy program appears to have more support in decision-making circles (ibid.). There are initiatives being developed by the private and academic sectors which would utilize solar energy further, but they have to compete with the JAEC and nuclear energy initiatives for funding and governmental support.

On April 1, 2007, the then Jordanian Energy Minister, Khaled Sharida, announced that Jordan intended to build one nuclear power plant to produce electricity by 2015 (Stern, 2007). This announcement led observers to ask questions relating to economic development, environmental sustainability, military and nuclear security, and energy security (see Caravelli 2011; Marktanner \& Salman, 2011). In particular, the development of a national nuclear energy program can become a major international political issue because of the perceived objectives and rationale behind it. The Jordanian government, through the Royal Court and the JAEC, for example, has often highlighted that energy security is one of the main challenges it faces (see Araj, 2010).

There are competing explanations as to why the Jordanian government has placed so much emphasis on nuclear energy generation. On the one hand, nuclear energy is genuinely seen as the most efficient, affordable, and effective solution to Jordan's energy needs in the medium to long term by parts of the Jordanian government (such as the JAEC). On the other hand, the position held by those who do not support the nuclear energy program is that the governmental bodies charged with finding solutions to Jordan's energy security needs have not given sufficient consideration to the alternatives to nuclear technology (Abu-Dabbouh, 2012). For example, on May 30,2012, a majority of deputies in the Lower House of the Parliament voted in favor of a recommendation by the Parliament's Energy and Mineral Resources Committee to halt work on the nuclear program. The legally binding recommendation called for a hold on any further development of the program until economic and environmental feasibility studies are completed and the JAEC releases complete information on the expected costs of the program (Omari, 2012). In reply, the JAEC declared that its activities will continue as they are in line with the requirements of the parliamentary recommendation as work was only being done on completing an economic feasibility study (Luck, 2012c).

Regardless of how the government's interest in nuclear energy has arisen, its perception of its planned nuclear energy program is quite clear. King Abdullah II himself has been a key advocate of the nuclear program 
and has charged the JAEC to pursue nuclear energy as a priority (HRH King Abdullah II, 2012). King Abdullah has also expressed concern and disappointment with the delays and difficulties in establishing the program the country has faced-even officially blaming the Israeli government for sabotaging his government's attempts to cooperate with nuclear supplier states (HRH King Abdullah II, 2012). Official statements from the Royal Court, the Ministry of Energy, the Jordanian Nuclear Regulatory Commission (JNRC), and the JAEC (Araj, 2010), as well as discussions taking place within these institutions, highlight that the government has several key opinions on nuclear energy. First, there is the view that Jordan faces a severe energy security challenge that is restricting development, reducing quality of life in Jordanian society (through rising living costs), and is untenable even in the short-term future. Second, there is a belief that Jordan has inalienable rights as a signatory of the NPT; that it has been entirely transparent about its nuclear energy plans; and has been forthcoming by approaching members of the international community and signing bilateral nuclear cooperation agreements. ${ }^{6}$ Third, the Jordanian government believes that it has long been a supportive ally of the US and other Western powers in international relations more broadly, and in particular has been a stabilizing and peaceful actor in the Middle East. At the same time, the Jordanian government sees the US as a key ally that has supported Jordan's political and economic goals - with the USJordan Free Trade Agreement (FTA) (discussed later) demonstrating the close relationship they enjoy.

In short, the Jordanian government has identified key policy drivers: its desire to increase domestic energy supplies while reducing energy imports in order to achieve a greater sense of energy security. It is expected that this, in turn, will facilitate further industrialization, poverty reduction, the desalination of sea water to produce freshwater (which requires significant energy input, which Jordan currently does not have the capacity for), and other aspects of economic development. The policy output of the government's assessment is to pursue a national nuclear energy program. Furthermore, the government's approach regarding bilateral and multilateral agreements, its transparency with its plans and capabilities, as well as its rights under the NPT and the additional protocols signed have led the government to develop plans for a domestically fuelled nuclear energy program. Here, the discovery of up to 120,000 tons of uranium ore in Jordan over the past several years (Touqan, 2012) combined with these policy goals and self-perceptions have compelled the decision-makers in Amman to conclude that their nuclear energy program should include 
the capacity to mine and enrich domestic uranium in order to provide fuel for its nuclear reactors (ibid.). According to Khaled Touqan, the Jordanian government views buying nuclear fuel on the international market to be unnecessary and that this would leave Jordan in the same situation of vulnerability as it now finds itself in. On the other hand, having a domestic source of energy would significantly reduce its vulnerability, energy insecurity, and budget deficit (ibid.).

With this conviction, the JAEC is due to select one bid from a choice of three short-listed to build Jordan's first nuclear reactor (Luck, 2011a). The vendor selected will be given a contract to build and operate the reactor which is likely to be a Generation III 1,000 MW reactor and is scheduled to come online by the end of 2018 (Touqan, 2012). The multinational corporations (MNCs) short-listed are as follows: a joint bid by AREVA (French) and Mitsubishi Heavy Industries (Japanese), Canadian AECL, and the Russian firm, Atomstroyexport. AREVA has also been involved in uranium exploration in Jordan since 2009 and in 2010 , signed an agreement to continue explorations and mine uranium ore (Luck, 2012d). Site location and safety studies have been conducted by Tractebel Engineering (a Belgian corporation) since late 2009 (Attwood, 2009) and a site near Mafraq has been suggested as the location of the first nuclear power plant.

Jordan has institutionalized cooperation with a number of key international actors in the form of nuclear cooperation agreements. However, the first such agreement that the Jordanian government pursued, a "123" agreement with the US, has not been signed and negotiations which started in early 2008 have been suspended since early 2011 (Luck, 2011b).

\section{The US Policy toward Jordan}

The US-Jordanian " 123 " nuclear cooperation negotiations that took place from 2008 until early 2011 were problematic (Luck, 2011b). The Jordanian government approached the US administration in late 2007 before turning to other governments but an agreement was never reached. ${ }^{7}$ While Jordan and the US have long had a constructive relationship and been close allies (with Jordan receiving major non-NATO [North Atlantic Treaty Organization] ally status from the US on November 12, 1996), the sensitivity of issues related to nuclear technology has proven to be insurmountable thus far. The key problem in the negotiations was the Jordanian government's intention to enrich uranium ore within its own 
borders in order to provide itself with domestically sourced fuel for its planned nuclear reactors. However, the US position on this matter fits into its broader international policy of limiting enrichment capacity and so, Washington has insisted that Jordan forego the right to enrich uranium (and develop other sensitive technologies such as the production of heavy water) in order for a "123" agreement to be signed (Kerr, 2012).

The Obama administration has made it clear that it views securing vulnerable nuclear fuels and strengthening international efforts to manage nuclear fuel cycles as a top priority. At the opening plenary session of the 2010 Nuclear Security Summit hosted in Washington, DC, President Obama remarked that "[t]wo decades after the end of the Cold War, we face a cruel irony of history - the risk of a nuclear confrontation between nations has gone down, but the risk of nuclear attack has gone up" (Obama, 2010). President Obama reiterated this point about international security and non-proliferation at the 2012 Nuclear Security Summit held in Seoul, South Korea, stating in his opening remarks:

[t]here are still too many bad actors in search of these dangerous materials, and these dangerous materials are still vulnerable in too many places. It would not take much - just a handful or so of these materials - to kill hundreds of thousands of innocent people. And that's not an exaggeration; that's the reality that we face. (Obama, 2012)

In addition, the US government views the creation of nuclear fuel banks as important in managing the global nuclear fuel cycle and nuclear materials, and ensuring that they are not diverted for use in weapons. According to this US position, new enrichment capacity in Jordan or other states developing nuclear energy programs would undermine this strategy and its goal of managing nuclear fuels (Kerr, ${ }^{8} 2012$ ). In 2005, for example, the US announced that it would use 17.4 tonnes of its surplus highly enriched uranium to be reprocessed as low-enriched uranium to be used as a fuel reserve. This fuel bank, called the American Assured Fuel Supply (AFS), would be used to supply other states with fuel for nuclear power stations. The then Secretary of Energy, Samual Bodeman, described this initiative as helping countries to pursue nuclear energy "without the burden of producing their own fuel, while curbing the spread of sensitive technology" (NNSA, 2006). The AFS was declared operational on August 18, 2011 (NNSA, 2011).

In February 2006, the US government proposed an international partnership initiative that would facilitate cooperation between states in 
developing the use of nuclear technology for energy purposes as well as create a regime to manage the nuclear fuel cycle. This initiative became known as the Global Nuclear Energy Partnership (GNEP) and by early 2007, over 20 states had joined, including Jordan. The intention of the GNEP was to coordinate international processes for mining, enriching, and transporting uranium and other materials for use in nuclear energy reactors (Nikitin, Andrews \& Holt, 2011, pp. 27-30). The initiative called for the maintenance and enhancement of the status quo with uranium enrichment capacity remaining under the control of those states which already supply enriched nuclear fuels to the international market and those who do not have the capacity being unable to develop it in the future. Under the initiative, uranium ore would be mined in producer states, exported to be enriched in states that have these facilities, like the US, and then exported for use in nuclear plants. Producer states would be able to sell their uranium ore but would have to buy back enriched uranium (which, naturally, would be more expensive in relative terms). Spent fuel would also be sent to the states with advanced capacities to be stored or reprocessed and re-exported again as fuel (ibid., pp. 27-29).

Under this regime, Jordan, for example, would be allowed to mine uranium ore but would not develop its own enrichment capabilities. Instead it would export the ore to an advanced nuclear state, say, the US, and then buy back enriched uranium, while the reprocessing state would be able to export the remaining enriched uranium. According to Khaled Touqan, Jordan may be able to mine over 60,000 tonnes of uranium ore but would only need approximately 300 tonnes of processed ore for its own nuclear energy program (Touqan, 2012). The potential remaining ore represents a significant future export commodity for Jordan.

For the US government, the GNEP initiative represented a reinforcement of international efforts to manage nuclear fuels and ensure security challenges were minimized (non-proliferation of weapons) (Nikitin et al., 2011, pp. 27-29). However, the GNEP has also been seen as reinforcing discrimination between producers and consumers, ensuring the dependency of states that do not have enrichment capability on those that do. By mid-2009, support for the project had begun to wane and even in the US, Congress announced the end of funding for domestic projects in the US that were linked to the GNEP (such as the research and development of further reprocessing and storage technologies). In 2010, the GNEP was replaced by the International Framework for Nuclear Energy Cooperation (IFNEC) which preserves the key focus on nuclear fuel cycle 
management set out in the GNEP in terms of limiting the proliferation of enrichment capabilities (IFNEC, 2011). The US position on Jordan's plans to include enrichment capacity in its program corresponds directly to the IFNEC policies (Kerr, 2012), demonstrating how the US policy toward Jordan sits within this broader framework.

Another concern, as discussed in a recent Congressional Research Service paper (Kerr, Holt \& Nikitin, 2011), relates directly to the proliferation of uranium enrichment capabilities and the impact this would have on increasing the amount of enriched uranium on international markets. This appears to be linked to the US and Russian plans to expand their own enrichment capabilities as part of the process of converting highly enriched uranium from dismantled nuclear weapons into low-enriched uranium for use in nuclear power plants (ibid.). This anticipated extra supply of fuel along with current global enrichment capabilities means there is enough fuel for current and planned nuclear energy plants for the next decade or so and, therefore, there is no need for extra fuel on the world market at this time (Squassoni, 2009).

The US-Jordanian negotiations went on at a much slower pace than those with other states with which Jordan has signed agreements. The slow pace of these negotiations is very interesting in light of how rapidly the US and Jordanian governments have managed to sign major agreements in the past decade or so, in particular the FTA of late 2000 which, at the time, was only the fourth bilateral FTA signed by the US. The US government argued that Jordan does not need to enrich uranium domestically but should instead sell its uranium ore resources on the global market and buy back enriched uranium from the cheapest supplier according to market mechanisms (Touqan, 2012). Amman, on the other hand, has not agreed to this claiming that it would simply leave it in the same position of relying on external sources of fuel that has caused its current energy insecurity and budgetary woes.

It is important to note that a 2009 " 123 " agreement between the US and the UAE for nuclear energy development in the latter included text that stipulates that the UAE will not seek to enrich uranium domestically but will purchase it on the global market (United States of America Department of State [USADS], 2008). This agreement is now often referred to as the "Gold Standard" (see Anon, 2011, p. 7) in Washington circles and is seen by the Jordanian government as somewhat weakening the case for its own uranium enrichment plans. The US-UAE agreement states that the latter will not seek to enrich uranium ore or reprocess spent 
fuel and that if it should seek to do so, bilateral cooperation in this field would cease (Blanchard \& Kerr, 2009, p. 6). Indeed, at the same time that Jordan and other Middle Eastern states are planning to develop nuclear energy programs with enrichment capacity, the US and other current nuclear states are developing plans for a multilateral nuclear fuel bank entailing maintenance of the status quo in terms of who has enrichment capacities (Lettow, 2010).

According to a senior member of the US Department of State's Office for Nuclear Energy Safety and Security (which was responsible for negotiating the "123" agreement with the Jordanian government), the US government perceives Jordanian interests and policy with regards to its nuclear program, and the US-Jordanian relations in general, in a broader global context (Anon, 2012). ${ }^{9}$ Here, there seems to be a great deal of concern in decision-making circles in Washington when it comes to control over nuclear fuels and the number of sources for enriched uranium internationally. A large number of Hearings at the House of Representatives' Committee on Foreign Affairs that deals with nuclear technology proliferation, for example, are dominated by discussions of weaponization, terrorist threats, and rogue states (ibid., 2011). In particular, Iran features prominently when the Middle East is discussed. In other Congressional debates, there is certainly a sense that consideration of the national interests of some developing states is up against consideration of US policies relating to broader international/global processes - and the latter tends to overcome the former. Hearings in the Senate Committee on Foreign Relations demonstrate the same tendency.

Ultimately, the US does not perceive the Jordanian case as unique or exceptional-while, naturally, the Jordanian government does. It is this perception disparity that seems to have hindered bilateral negotiations and eventually led to their suspension. Concerns over the direction of political change in the Middle East and how this would affect Jordan also are likely to have been central in the US policy and the timing of the suspension of the negotiations - which maps directly to the start of the Arab Spring and destabilization in some states in February and March 2011. However, some bilateral governmental cooperation has taken place, simply not within the context of a "123" agreement. For example, in 2010, the US Department of Energy provided funds through its Global Threat Reduction Fund for the construction of Jordan's first storage facility for nuclear waste (Hazaimeh, 2010). The supply of technology, financial resources, and expertise in the construction of power plants and related 
infrastructure will not, however, be permitted in the absence of a "123" agreement and US-based corporations will not be allowed to be involved in Jordan's program.

\section{Conclusions}

In understanding how the Jordanian government perceives its planned nuclear energy program, we have to consider how it perceives the energy security problem the country faces, its economic and political interests, and its capabilities. A near-total dependency on external sources of energy has resulted in a growing fuel bill that accounts for a large portion of GDP and the government's growing budget deficit. As confirmed by Khaled Touqan (2012), the Jordanian government perceives energy security as one of its primary short- to medium-term goals and believes that this is clear for external actors (such as the US) to see. The Jordanian government (and the JAEC in particular) believes that new domestically fuelled energy programs are necessary to, first, meet the current and projected domestic energy demand, and second, to reduce Jordan's energy insecurity. In the case of the nuclear energy program, the Jordanian government perceives itself as having the right to enrich its domestically sourced uranium to ensure its planned reactors will have a secure supply of fuel. In addition, the government sees the nuclear program as being transparent.

The US government does not hold the same views of at least some elements of Jordan's planned program. In particular, the US government has not supported the Jordanian desire to enrich uranium domestically. This position is consistent with broader US policies on nuclear technology proliferation and is not specific to the Jordanian case. Concerns over the proliferation of sensitive nuclear technologies and organization within the global nuclear fuel market are paramount here and considerations of Jordan's energy insecurity are not significant enough to overrule the broader US policy. Satisfying the Jordanian desire for reliance on domestic fuel sources is simply not as important as ensuring that nuclear fuels remain controled internationally (the potential costs outweigh the benefits in this case). Ultimately, the perceptions-agency nexus in Washington and Amman are not compatible with each other, and the Jordanian and US perceptions of the former's energy insecurity, the aims and capacities of its planned nuclear program, and the need for uranium enrichment are not in line with each other. While there are no indications that this will change in the coming years, the Jordanian government is still likely 
to pursue nuclear energy without an agreement with the US, and in turn, the US is not likely to sign future agreements that offer less than the US-UAE agreement of 2009.

Further study on this bilateral relationship and others seems necessary in order to more fully understand how decision-makers' perceptions can change over time and how the intersubjective meanings assigned to national interests interplay with perceived national capabilities in nuclear policy. Applying a model combining perceptions of self, other, and agency to the US-Jordanian "123" negotiations has allowed us to test its applicability to bilateral nuclear relations. This study demonstrates the value of contributing to analyses which consider states as unitary actors by considering decision-making processes within the state and the impact that differing socially constructed perceptions can have on policy and ultimately, whether cooperation emerges. Having tested this model on this case stud, however, it is clear that while it is applicable and can further our analyses of this case study and others, it could be useful to deepen the analysis to include an assessment of the impact of no nuclear cooperation on other issues and processes in the US-Jordanian relationship.

\section{NOTES}

1. States that already have advanced nuclear programs (both weaponized and/or civilian), including the United States (US), the United Kingdom (UK), France, Russia, and Germany.

2. So named after Section 123 of the US Atomic Energy Act of 1954, titled "Cooperation with Other Nations," which establishes the conditions for any nuclear cooperation between the US and other countries.

3. In order to understand the nature of the Jordanian nuclear energy program and how the Jordanian and US governments view its purpose, I have carried out an extensive literature review of primary and secondary sources covering academic, governmental, and private sector material relating to the Jordanian nuclear energy program. In addition, I have conducted in-depth interviews with key decision-makers, including His Excellency Dr Khaled Touqan, Chairman of the Jordan Atomic Energy Commission (JAEC) and the chief negotiator with the US; Haifa Al-Khraisha, the Head of the International Affairs Unit of the Royal Court; and leading members of the scientific and academic communities in Jordan, along with senior members of the US Department of State's Office for Nuclear Energy Safety and Security, and the US Congressional Research Service. 
4. India acquired nuclear weapons in 1974, and had fought wars with China (1962) and Pakistan (1947-1948, 1965, 1971); Israel is implicitly believed to have acquired nuclear weapons possibly as early as 1965 (exact year unknown due to the undeclared nature of Israel's program) and had fought wars with neighboring states in 1948 and 1956; Pakistan acquired nuclear weapons in 1998 and had fought wars with India (1947-1948, 1965, 1971); and North Korea acquired nuclear weapons in 2006 having fought the 1950-1953 war with a coalition of states led by the US and South Korea.

5. Ayman Maytah is Vice President of the American University in Madaba and Jordan's leading solar energy specialist.

6. At the time of writing, 11 bilateral agreements had been signed: Argentina, Canada, China, France, Japan, Romania, Russia, Spain, South Korea, Turkey, and the UK. Negotiations were being held with three others: Czech Republic, Italy, and the US (suspended).

7. Although this author has seen a signed copy of a US-Jordan "123" agreement dated 7 February 2008, it was (according to the Jordanian government) canceled by the US several months later. The US Department of State's Office of Nuclear Energy Safety and Security has declined to comment on this particular issue.

8. Paul Kerr is a senior analyst on nuclear non-proliferation at the US Congressional Research Service, Washington, DC.

9. The interviewee wished to remain anonymous as the interviewee was not authorized to comment on Jordan's nuclear energy program or the US-Jordanian relations.

\section{REFERENCES}

Abu-Dabbouh, W.K. (2012, February 27-29). The energy situation in Jordan. The Fourth German-Jordanian Workshop: International Solar Energy Conference, Amman, Jordan.

Abu-Lebdeh, H.S. (1997). Conflict and peace in the Middle East: National perceptions and United States-Jordan relations. Lanham, MD: University of America Press.

Andrain, C., \& Smith, J. (2006). Political democracy, trust, and social justice: A comparative overview. Lebanon, NH: North-eastern University Press.

Anon. (2011, March 17). The global nuclear revival and US non-proliferation policy. Serial No. 112-7, Hearing before the Committee on Foreign Affairs, House of Representatives 112th Congress First Session.

Anon. (2012). Interview conducted in Washington, DC, US, 12 March. 
Aquastat Database. Retrieved January 10, 2014, from http://www.aquastat environmentalservices.co.uk/

Araj, K. (2010, June 23-26). Jordan's nuclear power programme. The First Arab Conference on the Prospects for Nuclear Power for Electricity Generation and Seawater Desalination, Tunis, Tunisia: Jordan Atomic Energy Commission. Attwood, E. (2009, September 14). Jordan signs \$12 million nuclear deal with Tractebel. Arabian Business. Retrieved August 29, 2014, from http://www. arabianbusiness.com/jordan-signs-12m-nuclear-deal-with-tractebel-12835. html

Awad, T. (2009). The price of oil and the macro-economy: The case of Jordan. The Economic Observatory, February, p. 5.

Blanchard, C., \& Kerr, P. (2009). The United Arab Emirates nuclear program and proposed US nuclear cooperation. Washington, DC: Congressional Research Service.

Boulding, K. (1959). National images and international systems. Journal of Conflict Resolution, 3(2), 120-131.

Caravelli, J. (2011). Beyond sand and oil: The nuclear Middle East. Santa Barbara, CA: Greenwood Publishing Group.

CIA World Factbook (2011). Retrieved August 29, 2014, from https:/www.cia. gov/library/publications/download/download-2011/

Deese, D. (1979). Energy: Economics, politics and security. International Security, 4(3), 140-153.

El-Ashry, M., Saab, N., \& Zeitoon, B. (Eds). (2010). Water: Sustainable management of a scarce resource. Beirut: Arab Forum for Environment and Development.

El-Said, H. (2002). The political economy of reform in Jordan: Breaking resistance to reform? In G. Joffe (Ed.), Jordan in transition: 1990-2000 (pp. 254-277). London: Hurst and Co.

Fuhrmann, M. (2009a). Taking a walk on the supply side: Determinants of civilian nuclear cooperation. The Journal of Conflict Resolution, 53(2), 181-208.

Fuhrmann, M. (2009b). Spreading temptation: Proliferation and peaceful nuclear cooperation agreements. International Security, 34(1), 7-41.

Gartzke, E., \& Jo, D. (2009). Bargaining, nuclear proliferation, and international disputes. Journal of Conflict Resolution, 53(2), 209-233.

Grzelczyk, V. (2009). Six-party talks and negotiation strategy: When do we get there? International Negotiation, 14(1), 95-119.

Hazaimeh, H. (2010, July 4). Sharif: No problems facing Jordan-US nuclear talks. Jordan Times. Retrieved August 29, 2014, from http://jordantimes.com/ no-problems-facing-jordan-us-nuclear-talks---sharif 
HRH King Abdullah II. (2012). Press room release: Interview with His Majesty King Abdullah II. Retrieved August 29, 2014, from http://www.kingabdullah. jo/index.php/en_US/interviews/view/id/498/videoDisplay/0.html

International Framework for Nuclear Energy Cooperation (IFNEC). (2011, September 29). Steering group action plan: An action plan for the safe, secure global use of nuclear energy. Retrieved January 9, 2014, from http://www. ifnec.org/Portals/0/Docs/IFNEC/Appendicies/Appendix\%20B/IFNEC_Joint_ Statement_2011.pdf_

Jervis, R. (1976). Perception and misperception in international politics. Princeton, NJ: Princeton University Press.

Kerr, P. (2012). Interview conducted in Washington, DC, US, 27 March.

Kerr, P., Holt, M., \& Nikitin, M.B. (2011). Nuclear energy cooperation with foreign countries: Issues for Congress. Washington, DC: Congressional Research Service.

Knowles, W. (2005). Jordan since 1989: A study in political economy. London: I.B. Tauris.

Kroenig, M. (2009a). Exporting the bomb: Why states provide sensitive nuclear assistance. The American Political Science Review, 103(1), 113-133.

Kroenig, M. (2009b). Importing the bomb: Sensitive nuclear assistance and nuclear proliferation. The Journal of Conflict Resolution, 53(2), 161-180.

Leeds, B.A., Long, A., \& Mitchell, S.M. (2000). Re-evaluating alliance reliability: Specific threats, specific promises. Journal of Conflict Resolution, 44(5), 686-699.

Lettow, P. (2010). Strengthening the nuclear non-proliferation regime. Washington, DC: Council on Foreign Relations.

Luck, T. (2011a, February 7). Nuclear commission to bring international energy company on board. Jordan Times. Retrieved from August 29, 2014, from http:// jordantimes.com/nuclear-commission-to-bring-intl-energy-company-on-board

Luck, T. (2011b, March 16). Regional turmoil puts US-Jordan nuclear talks on hold. Jordan Times. Retrieved from August 29, 2014, from http://jordantimes. com/regional-turmoil-puts-us-jordan-nuclear-talks-on-hold

Luck, T. (2012a, January 18). Egyptian gas cuts to cost Jordan \$2.4 billion. Jordan Times. Retrieved from January 15, 2014, http://jordantimes.com/egyptian-gascuts-to-cost-jordan-24-billion

Luck, T. (2012b, May 8). First barrels of oil shale expected this year. Jordan Times. Retrieved January 15, 2014, from http://jordantimes.com/first-barrelsof-jordanian-oil-shale-expected-this-year

Luck, T. (2012c, May 30). Atomic energy programme to "go ahead as planned." Jordan Times. Retrieved January 15, 2014, from http://jordantimes.com/ atomic-energy-programme-to-go-ahead-as-planned 
Luck, T. (2012d, June 6). French firm ups uranium projections. Jordan Times. Retrieved August 29, 2014, from http://jordantimes.com/regional-turmoilputs-us-jordan-nuclear-talks-on-hold

Marktanner, M., \& Salman, L. (2011). Economic and geopolitical dimensions of renewable vs. nuclear energy in North Africa. Energy Policy, 39(8), 4479-4489.

Maytah, A. (2012a, February 27-29). CSP tri-generation system at Mutah University. The Fourth German-Jordanian Workshop: International Solar Energy Conference, Amman, Jordan.

Maytah, A. (2012b). Interview conducted in Amman, Jordan, 27 February.

Milner, H. (1997). Interests, institutions and information: Domestic politics and international Relations. Princeton, NJ: Princeton University Press.

Moran, D., \& Russell, J. (Eds). (2009). Energy security and global politics: The militarization of resource management. New York: Routledge.

National Nuclear Security Administration (NNSA). (2006, November 7). Reliable fuel supply gains momentum. NNSA Press Release. Retrieved January 15, 2014, from http://nnsa.energy.gov/mediaroom/pressreleases/doennsa-reliablefuel-supply-gains-momentum

National Nuclear Security Administration (NNSA). (2011, August 18). DOE/ NNSA announce availability of reserve stockpile of nuclear power reactor fuel material from down-blending of surplus weapons-usable uranium. NNSA Press Release. Retrieved January 15, 2014, from http://nnsa.energy.gov/mediaroom/ pressreleases/doennsaafs 81811

National Nuclear Security Administration (NNSA). (2012). 123 agreements for peaceful cooperation. Retrieved August 29, 2014, from http://nnsa.energy. gov/aboutus/ourprograms/nonproliferation/treatiesagreements/123agreeme ntsforpeacefulcooperation

Nikitin, M.B., Andrews, A., \& Holt, M. (2011). Managing the nuclear fuel cycle: Policy implications of expanding global access to nuclear power. Washington, DC: Congressional Research Service.

Nye, J. (2004). Soft power: The means to success in world politics. New York: Public Affairs.

Obama, B. (2010, April 13). Remarks by the President. Opening Plenary Session of the Nuclear Security Summit, Washington, DC.

Obama, B. (2012, March 26). Remarks by the President. Opening Plenary Session of the Nuclear Security Summit, Seoul, South Korea.

Obeidat, O. (2011, August 29). Jordan, Egypt to sign natural gas deal. Jordan Times. Retrieved August 29, 2014, from http://jordantimes.com/jordan-egyptto-sign-natural-gas-deal 
Obeidat, O. (2012, May 17). Oil Shale is Jordan's Saviour - International expert. Jordan Times. Retrieved August 29, 2014, from http://jordantimes.com/oilshale-is-jordans-saviour----intl-expert

Omari, R. (2012, May 30). Deputies vote to suspend nuclear project. Jordan Times. Retrieved August 29, 2014, from http://jordantimes.com/Deputies+ vote+to+suspend+nuclear+project-48497

Ruzicka, J., \& Wheeler, N.J. (2010). The puzzle of trusting relationships in the nuclear non-proliferation treaty. International Affairs, 86(1), 69-85.

Sagan, S. (1996). Why do states build nuclear weapons? Three models in search of a bomb. International Security, 21(3), 54-86.

Spero, J. (1973). Energy self-sufficiency and national security. Proceedings of the National Academy of Political Science, 31(2), 123-136.

Squassoni, S. (2009). Nuclear energy: Rebirth or resuscitation? Washington, DC: Carnegie Endowment for International Peace.

Stern, Y. (2007, April 2). Jordan announces plan to build power plant by 2015. Haaretz. Retrieved August 29, 2014, from http://www.haaretz.com/news/ jordan-announces-plans-to-build-nuclear-power-plant-by-2015-1.217260

Touqan, K. (Chairman of the Jordan Atomic Energy Commission). (2012). Interview conducted in Amman, Jordan, 5 March.

UN Comtrade Data. Retrieved January 15, 2014, from http://comtrade.un.org/ United States of America Department of State (USADS). (2008). US-United Arab Emirates Memorandum of Understanding on Nuclear Energy Cooperation.

Weldes, J. (1996). Constructing national interests. European Journal of International Relations, 2(3), 275-318.

Wendt, A. (1992). Anarchy is what states make of it: The social construction of power politics. International Organisation, 46(2), 391-425.

Imad El-Anis is a Senior Lecturer in International Relations at the Nottingham Trent University, UK. He is the author of several books, including Jordan and the United States: The Political Economy of Trade and Economic Reform in the Middle East (London: I.B. Tauris, 2011). [email:imad.el-anis@ntu.ac.uk] 